Iysimeter in an adjoining arable field, were two batteries of four lysimeters each, one under a stand of conifers and one under a stand of broad-leaved trees. These had been made by pressing large raingauge-shaped lysimeters upwards into the soil under the trees, from a horizontal gallery, painstakingly excavated to avoid disturbance of the natural conditions. The aim was limited to measuring differences in rates of recharge of soil-water, but they have not been operating long enough for the results to be assessed.

The third visit was to the installation of the Dortmund Waterworks at Geisecke on the Ruhr.
Here there are batteries of $(a)$ volume lysimeters, and $(b)$ weighing lysimeters, filled with different materials and with different vegetation covers. Although undoubtedly useful information is obtained, the results from type (a) might be queried in view of the very large amount of bare concrete surrounding the tanks, while in both types $(a)$ and $(b)$ reasonable homogeneity with the surrounding vegetation was achieved only in certain of the tanks. In fact, the series of records from each of these lysimeters, as at some other installations, could be considered only separately, and not safely compared with those from any of the others.

F. W. Green

\title{
OBITUARIES
}

\section{Prof. H. J. Backer}

Hitmar Johannes Backer was born at Dordrecht on January 13, 1882, and died at Glimmen, near Groningen, on April 29, 1959. He was a pupil at the Gymnasium in Dordrecht and studied at the University of Leyden under Franchimont in chemistry and H. A. Lorentz in physies. His doctoral thesis was entitled "De Nitraminen en hunne Electro-chemische Reductie". $\mathrm{He}_{\theta}$ also worked with Elbs at Giessen on the technique of electrochemical reduction and later in the Davy Faraday Laboratories at the Royal Institution in London. After two to three years on the staff at Leyden and a similar period in industry and in Government service, he was called to the chair of organic chemistry at Groningen in 1916 as successor to J. F. Eykman. His colleague, Dr. J. Strating, said that Backer soon showed his capacity for hard work, for concentration and for utilizing every free moment, and yet it seemed that the passage of years only increased his broad humanity.

A survey of his researches (1905-55) reveals an increasing occupation with compounds containing the - $\mathrm{SO}_{2}$ - group. This can be correlated with the early work of Franehimont on $\alpha$-sulphopropionic acid which Backer and Franchimont resolved in 1914 by means of strychnine. Backer then prepared and resolved $\alpha$-chloro- and $\alpha$-bromo-sulphoacetic acids, $\alpha$-seleninopropionic acid, $\alpha$-sulphobutyric acid, several $\alpha$-arsenocarboxylic acids and also chlorobromoacetic acid.

About 1930 he began a study with Strating of the unsaturated cyclic sulphones formed from sulphur dioxide and butadienes. The close relation of these compounds to the thiophens led to a study of the oxidation of thiophen homologues in the hope of obtaining the corresponding sulphones. Thiophen itself, on oxidation, gives a 'sesquioxide', presumably formed by $1: 4$-addition between the unstable sulphoxide and sulphone of thiophen. It was found that certain dialkyl- and diphenyl-thiophens gave sulphones on oxidation; tetraphenylthiophon had long been known to do so. This was attributed to the presence of the substituents which increased the electron availability on the sulphur atom. In some cases a sesquioxide was formed. On the other hand, electron-attracting groups in the benzene nucleus of $3: 4$-diphenylthiophen inhibited sulphone formation.

In 1952 Backer began to study imenes of the type $\left(R \cdot \mathrm{SO}_{2}\right)_{2} \mathrm{C}=\mathrm{C}=\mathrm{N} R^{\prime}$, which are very reactive. Three of these have recently boen submitted to X-ray analysis by Wheatley, Bullough and Daly in Leeds with very interesting results.

At the beginning of the occupation of the Netherlands in 1940, Backer gave much help and advice to his students, whose whole world had suddenly fallen to pieces. He kept in touch with all those who were forcibly deported to Germany, sent them parcels and encouraged and advised their parents. When I visited Backer in 1947, he referred only briefly to his imprisonment in 1945 and said nothing of the physical violence which he endured during interrogation. The other occupant of his cell was shot. The liberation of Groningen probably saved Backer from the same fate.

Later on, two of my research students visited Groningen at Backer's invitation, lived in his house for some weeks and worked in his Department. Dr. A. Ash wrote: "It was his habit to have students lodging with him and he liked nothing better than for students to call in the evening for a short talk; help or advice were gladly given. $\mathrm{He}$ interested himself also in their social life. He methodically inquired of his students' progress every morning and imparted an impressive practical technique particularly rich in devices for facilitating manipulation of small quantities". Dr. A. G. Lowther has said : "One's immediate impression on meeting him was that here was a man who demanded one's respect and affection. This was not only a first impression-it was there among his students--they had a real affection, almost love, for Prof. Backer. He never appeared to be hurried, was most courteous and had a quiet, but real, sense of humour. I never heard one word of criticism of him ... there was a serenity about him and his house".

Dr. Strating wrote: "Nothing could prevent him from helping a friend or a student who was in need, and this, no doubt, led to his arrest". Backer was a knight of the Order of the Netherlands Lion, a member of the Royal Academy of Sciences in Amsterdam, a correspondent of the Paris Academy of Sciences and an honorary member of the Solvay Institute in Brussels. He received honorary doctorates from the Universities of Ghent and Lille.

When those who knew him recall Backer's achieve. ments as a man and as a chemist, his great capacity for friendship and for hard work, his fearlessness and his quiet mind, they feel that he went far towards solving happily the oternal problem, si jeunesse savait, si vieillesse pouvait. Freiderick Chaldenger 